\section{Time to resist earmarks}

A US Congressman's fight against earmarked funds needs and deserves more public support from the universities.

Congressman George Brown (Democrat, California) continues to pursue his single-handed battle against academic earmarking with tenacity and some imagination. Despite recent setbacks, he has just opened up a new front in his campaign, demanding that energy secretary Hazel O'Leary resist the diversion of money from the Human Genome Project into a senator's pet project.

Brown's letter to O'Leary serves the public well, highlighting the earmarking process at its most insidious. It asks her to consider the particular case of $\$ 1.1$ million cut from her department's contribution to the Human Genome Project to pay for new Apple Power PCs at the Oregon Health Science University.

The Oregon school does no research at all for the energy department - yet according to Brown it has received $\$ 96$ million in earmarks, mostly from the energy pot, since 1983. Senator Mark Hatfield (Republican, Oregon) is the ranking republican member of the Energy and Water Development appropriations subcommittee.

The energy department spends plenty of time agonizing over what to cut, but makes no attempt whatsoever to evaluate the scientific value of the earmarks themselves. Brown has told O'Leary that she can spend money on earmarks if she wants, "but I expect you to have a more compelling reason than a desire to placate a distinguished senior Senator on the Appropriations Committee".

The earmarkers, being a surreptitious bunch, rarely make their case in public, but they basically have three arguments in their favour.

The worst one is that they send money to small schools, while a proper peer review process favours the likes of Harvard and Massachusetts Institute of Technology. This is like the Mafia defending extortion on the grounds that it boosts the economy. If the weaker schools are treated unfairly by peer review - and a recent study by the Government Accounting Office found that they are not - then the solution rests with better peer review procedures, not with the arbitrary favours of the earmarking system.

Slightly more convincing is the appropriators' charge that the federal budget allocates next to nothing for new university buildings, and that only earmarks can get them built. Last month's Science in the Public Interest document from the White House should have stated how this perennial problem is going to be resolved. Instead it promised that the National Science and Technology Council would "develop options". It must do so with greater urgency than has so far been evident.

The third and most telling argument for earmarking is simply that a cynical public expects nothing less and nothing more. When the powerful and allegedly corrupt former chairman of the House Ways and Means committee, Dan Rostenkowski, faced a severe primary challenge in his
Chicago district earlier this year, he duly arranged for the federal government to deliver new helicopter ambulances to local hospitals during the campaign - which he won handsomely. George Brown has actually been criticised in California for complaining about earmarking instead of getting on with the business of abusing his position in Congress to bring home the bacon. The public, some would argue, gets the government it deserves.

The setback for Brown's anti-earmarking campaign came last month (see Nature 369, 694; 1994) when John Murtha (Democrat, Pennsylvania), chairman of the House defense appropriations subcommittee and earmarker par excellence, threatened to cut the defence department's $\$ 1.8$ billion university research budget in half. If this was intended to scare the universities into silence on the earmarking issue, it must not succeed.

Congressman Brown, of course, has his own agenda: his attacks on appropriators are designed, in part, to nurture the influence of the Science, Space and Technology authorization committee which he chairs. Nonetheless he has occupied the high moral ground. It is time for the scientific community to join him there: otherwise, it will be correctly judged as just another special interest group with its nose in the public trough.

\section{Germany and the bomb}

The likelihood that a cartel is forming to sell bomb-grade plutonium exported to Germany is a cause for alarm.

LAST week German officials seized some 500 grams of radioactive plutonium 239 from luggage aboard a flight from Moscow to Munich. It was the third and largest recent seizure of plutonium that appears to have originated in Russia (despite the denials of Russian officials) and suggests that an organized plutonium cartel is at work.

So far, officials have acknowledged two other seizures of weapons-grade material. Plutonium 239 was found in a garage in Germany in May; enriched uranium 235 was seized in Bavaria in June. German officials claim that scientific analysis shows that the fissionable material comes from Russia, while Russian spokesmen say there have been no losses of plutonium from any of their facilities, with the possible exception of missing medical-grade material. But the radioactive isotopes used in medicine would not, in any case, be useful for building bombs and bombs are what are at issue here.

The end of the Cold War has lead to the faulty presumption that the world is now a safer place. Witness the apparent decline in weapons-building activity by the US Department of Defense. But in fact, the possibility that terrorists or unstable small governments may acquire the ability to build nuclear warheads is as destabling a threat as there could be. And it should go to the top of the list of concerns among all of the nations of the world. This is not just the making of a good novel of international intrigue. It threatens the stability (and viability) of the world. 